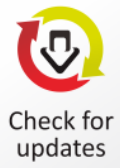

updates

\section{Analysis of the Prospect of Implementing Activity-Based Costing (ABC) in Governmental Organisations: A Study at the State Treasury Office Jakarta IV}

\author{
Tri Priyatmo ${ }^{1 *}$ and Rusdi Akbar ${ }^{2}$
}

\begin{abstract}
This research aims to analyse the prospect of implementing ActivityBased Costing $(A B C)$ at governmental organisations in Indonesia. The study aims to answer two research questions: how can we calculate the unit cost of products using the $A B C$ method in a governmental organisation? $\left(R Q_{1}\right)$; and, what is the prospect of implementing $A B C$ in governmental organisations? $\left(R Q_{2}\right)$. The study comprises qualitative research undertaken at one governmental organisation, that of the State Treasury Office (KPPN) Jakarta IV. The research reveals that the ABC method can be used to calculate the unit cost of products in KPPN Jakarta IV, and also to obtain a conceptual framework by which it is possible to conclude that the $A B C$ method has a positive outlook as an analytical tool. However, one of the study's research objects, the prospect of implementing the $A B C$ method in this research, cannot be generalised for all governmental organisations in Indonesia. However, based on the results of this research, it can be stated that there is a shared understanding of the potential for the implementation of the $A B C$ method in the future. This study is the first of its kind to investigate this topic and will yield new insight within the literature on the $A B C$ method in Indonesia.
\end{abstract}

KEYWORDS: activity-based costing ( $A B C)$; unit cost; prospects; governmental organisation

Citation:

Priyatmo, T., \& Akbar, R. (2019).

Analysis of the Prospect of

Implementing Activity-Based Costing $(A B C)$ in Governmental Organisations: A Study at the State Treasury Office Jakarta IV. Journal of Accounting and Investment, 20(1), 1-22.

Received:

09 April 2018

Reviewed:

02 May 2018

Revised:

30 September 2018

Accepted:

04 October 2018

Copyright: (C) 2019 Priyatmo \& Akbar. This is an open access article distributed under the terms of the Creative Commons Attribution License, which permits unrestricted use,

\section{Introduction}

To guarantee the efficient and effective allocation of resources, reliable and accurate management information is needed that is relevant for calculating the level of programme, activity or project costs. A good management information system is able to reduce the chance of corruption, leaked funds and also highlight those programmes that are not economically feasible. Management accounting in the public sector faces three problems: costefficiency, product quality and service (Mardiasmo, 2009).

Based on The Global Competitiveness Report 2015-2016, Indonesia ranks $37^{\text {th }}$, behind Malaysia and Thailand, in terms of the measurement of countries' effectiveness in using the available resources for the prosperity of their citizens (WEF, 2016).

With regard to the Worldwide Governance Indicators based on World Bank data and surveys for the period 1996-2016, four of the six indicators relating to the performance of the Indonesian government were negative. These four minus indicators relate to regulatory quality, rule of law, control of corruption, and political stability and the absence of violence/terrorism. The 
distribution, and reproduction in any medium, provided the original author and source are credited. country scored positively against the indicators of voice and accountability and government effectiveness. However, the report also revealed that the average score for the Indonesian government on the effectiveness index in 2016 remained very low, with an index value of 0.01 and a ranking of 86th (World Bank, 2017).

Cost management provides one means by which public sector effectiveness can be increased. Cost management is used to calculate the cost of products, services and other cost objects; to obtain information for planning and control and performance evaluation; and to analyse the relevant information for the purpose of decision-making (Horngren, Datar, Foster, Rajan, \& Ittner, 2009). Verbeeten (2011) showed that a cost management system is more aimed at legitimising organisational activities towards external stakeholders. Public sector organisations in the Netherlands have also been asked or pressured into introducing cost management practices with the aim of improving the economy and/or efficiency.

Cokins (2015), through the International Federation of Accountants (IFAC), states that Activity-Based Costing ( $A B C)$ is one method by which to accurately derive data on government costs (IFAC, 2016). In line with this view, Cai, Moore, and McNamara (2013) conducted research on 28 health service centres in New South Wales Justice and the Forensic Mental Health Network (NSWJ \& FMHN) with the aim of developing an Activity-Based Funding (ABF) model. The ABF model was structured through the three key phases of diagnostics, solution design and implementation involving local managers and doctors. As a result, it was possible to determine the cost per treatment episode by dividing the amount of the doctor's service fees in each clinical building block by the number of appointments completed by the doctor. The building blocks classify clinical activities and related costs by the types of doctors involved in providing the services. This project resulted in an $A B C$ model based on the actual activities carried out, which subsequently gained the acceptance of doctors and managers and provided a basis for efficiency and benchmarking efforts.

According to Chea (2011), the ABC method offers the following advantages. It may increase operational performance by allocating overhead costs based on the actual consumption of resources by each activity; it recognises the interdependence between the cost driver and activities; it enables management to see where the most important costs are incurred and what they provide, and it provides a suitable method for correct and accurate information. In addition, ABC can reveal the source of non-value-added for value-added activities. By accurately identifying weak product lines and cost, $A B C$ helps to improve organisational efficiency and profitability. It can be used to completely eliminate non-value-added activity and can encourage growth by removing the barriers that lead to capacity constraints.

Harrison (1998) compared the information generated by ABC with that from a traditional costing method, in this case Volume-Based Costing (VBC). The study revealed that by the time the processes were relatively the same, the information generated by $A B C$ led to better decision-making with regard to maximising profit. 
Yet the ABC method also has its drawbacks. According to Chea (2011), ABC entails significant time and cost, which acts as a burden for the organisation. The $A B C$ system implementation process is very complex for managers to understand and generates a lot of data, in addition to the inspection process. It may encounter resistance from management since they are accustomed to using conventional cost systems in the running of their operations (Roztocki, Porter, Thomas, \& Needy, 2004).

In Indonesia, the government does not have a method for use in analysing product costs within its governmental organisations. This means that the results of this study will contribute empirically in terms of providing a method for the management of governmental organisations in Indonesia to manage cost information for efficiency purposes, employee empowerment and performance assessment tools. In addition, this research can contribute theoretically to enriching the $A B C$ theory literature in the public sector, especially on $A B C$ in the Indonesian public sector.

\section{Literature Review and Research Focus}

\section{Cost Analysis in Indonesia}

This research is based on the fact that up to now the government has not conducted a cost analysis of any products/services produced by governmental organisations, especially governmental organisations that do not charge for the products produced. This absence of any form of cost analysis by the government has resulted in not knowing the benchmark cost of each unit of product from each governmental organisation. This also means that the government is unable to measure the efficiency with which costs are incurred by each governmental organisation to produce each unit of government products.

There is a future expectation that the cost per unit of government products can be calculated to be both accurate and comparable. The ability to analyse product cost data also serves as a tool for management decision-making. For this to happen, the right cost analysis method needs to be applied in Indonesia. ABC is an alternative method that has been recommended for use in the public sector by, for example, Michel (2004), Cai et al. (2013), and Cokins (2015). Therefore, the authors are encouraged to conduct further research on the prospect of implementing the $A B C$ method in a governmental organisation in Indonesia, namely KPPN Jakarta IV.

Although the highest limit and estimated annual costs are stated in Finance Minister Regulation (PMK) Number 65/PMK.02/2015 on Standard Input Cost for Fiscal Year 2016 and PMK Number 115/PMK.02/2015 on Standard Output Cost for Fiscal Year 2016, the boundaries of these costs are based only on input costs. Cost analysis based on actual cost data is therefore required to calculate both the cost of government services by product as well as to obtain information on business processes for organisational management. 


\section{The Meaning of Cost}

Government Regulation (PP) No. 71 of 2010 on Government Accounting Standards does not mention the meaning of costs. Nevertheless, the concept of cost is divided into two, namely the Budget Realization Report (LRA), related to spending, and Operational Reports (LO), which relate to expenses.

Spending is all of the expenditure by the Public State Treasury/Public Regional Treasury that serves to reduce the Budget Balance over the period of the relevant fiscal year and which will not be earned back by the government payment. While expense equates to a decrease in economic benefits or service potential during the reporting period, which lowers the equities, it can take the form of either the expenditure or consumption of assets or the incurrence of a liability.

Thus, it can be concluded that the concept of costs associated with the product in this study means that all of the spending and expenses that are integrally associated with the process of acquiring goods or services are expected to benefit the present or future of the organisation.

\section{Classification of Cost}

Based on their relationship with product, Mowen, Hansen, and Heitger (2012) classified costs into the following three categories: (1) Direct material costs comprise all of the materials that form an integral part of the finished product that was explicitly included in the calculation of the product cost; (2) Direct labour costs represent the labour used to transform the direct material into finished products and which can be appropriately linked to a specific product; and (3) Overhead costs (factory overheads) are the manufacturing costs that cannot be traced directly to a specific product.

\section{Product Cost Calculation Methods}

Mowen et al. (2012) divide the cost of the product calculations into three methods: absorption costing, variable costing and $A B C$ :

Absorption costing seeks to account for the entirety of the manufacturing costs for products. The combination of direct labour cost, direct material costs, fixed overhead costs and variable overhead costs determine the cost of the product. Thus, in absorption costing, the fixed overhead cost is seen as the cost of the product, not the cost of the period.

Variable costing emphasises the difference between fixed production costs and variable costs. Variable costing focuses only on the variable production costs for the product. These include direct labour costs, direct material costs and variable overhead costs. Overheads are treated as an expense of the period in question and are excluded from product costs. This is based on the assumption that fixed overhead represents the cost of capacity, or, in other words, that which remains in the business. After the period ends, the 
benefits provided by the capacity have expired and, as such, it should not be inventoried.

While $A B C$ is a method of determining the cost of goods sold by counting all of the cost elements, the costs are calculated based on the amount of activity consumed by each product.

\section{ABC History}

The $A B C$ method was first introduced and developed in the United States in the 1980 s as a means of demonstrating a better calculation of product costs. Kaplan and Cooper (1998) state that ABC provides more accurate product costs in comparison to those derived using conventional methods. $A B C$ uses the level of activity consumption as the driver of costs. It then allocates these costs to products on the basis of activity cost drivers.

$A B C$ is used to measure the cost and performance of activities associated with the process and cost objects (Cokins, Helbling, \& Stratton, 1996). Weygandt, Kieso, and Kell (1996) provided the following definition of ABC: "ABC is the method of product costing that focused on the activities performed to produce the product. It then assigns the cost of activities to the product by using cost drivers that measure the activities performed.". According to Mulyadi (2007), ABC has two basic philosophies. First, the cost has a cause and the cause of cost is activity. Second, the cause of costs (activity) can be managed. According to Kaplan and Cooper (1998), ABC causally links the causal relationship between resources, activity (process) and cost product (see Figure 1). The process of cost charging begins with resource consumption and continues with the consumption activities by products/services.

Customer demands and competition encourage changes in business processes in every organisation, in both the private and public sectors. Computerisation and the automation of business processes have led to changes in cost behaviour. Costs were initially dominated by direct costs,

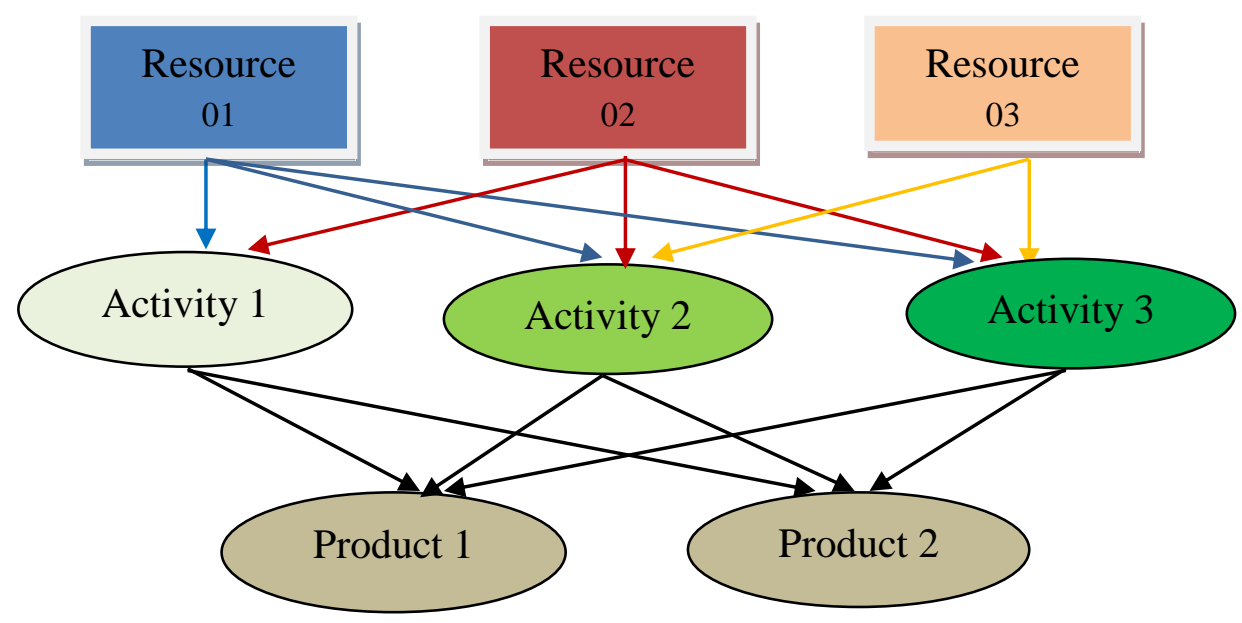

Figure 1 General Process of the ABC Method Source: Kaplan and Cooper (1998) 
which could reach as high as $90 \%$, prior to shifting by a significant portion of variable costs. Total variable costs have tended to increase, with the average proportion variable cost now accounting for more than $50 \%$ of the total cost (Popesko, 2009).

In relation to changes in cost behaviour, full costing and variable costing, collectively known as the conventional method, are considered irrelevant. The calculation of the unit cost of product/services via the conventional method is done by levelling each overhead cost into a variable of direct labour hours or machine hours. Thus, the results of the cost calculation for each product/service can become distorted, causing the information obtained and used by the organisation's management to be inaccurate (Mulyadi, 2007).

The $A B C$ method was introduced as a new alternative to calculating the unit cost of products in the private sector, especially in manufacturing companies. However, according to Chea (2011) and Michel (2004), ABC is not only suitable for a manufacturing environment but is also appropriate for service organisations such as financial institutions, industry, healthcare and governmental organisations. $\mathrm{ABC}$ has indeed been implemented in the public sector since the 1990s, with examples seen in Indianapolis and North Carolina, United States (Michel, 2004).

\section{Types of $A B C$ method}

Over the course of its development, the $A B C$ method has been modified as an alternative approach with the aim of improvement and cost-efficiency. The following are some of the modifications:

\section{Time-Driven Activity-Based Costing (TDABC)}

According to Kaplan and Anderson (2004), the most important characteristic of the TDABC model is its simplicity, since only two types of parameters are required for estimation: the number of units of time (e.g. minutes) consumed by the activities related to the cost objects, and the cost per unit of time.

\section{Analytic Hierarchical Process (AHP)}

Roztocki et al. (2004) argued that AHP is a suitable tool for gaining the subjective opinions of individuals to become more representative information. AHP generally employs the Expenses-Activity-Dependence (EAD) and the Product-Activity-Dependence (APD) matrices, both of which assist in the understanding of how overhead cost is generated. These matrices can also be used to identify opportunities for improvement. As the steps of a future software program based on this methodology, technology can be developed that will track the overhead costs for products accurately, at a low cost and in a short time. 
Mutually and Self-Consumed Secondary Activities

According to Popesko (2009), there are two types of activity: the main activity (primary) and support activities (secondary). The main activity is associated with the action taken by the organisation to meet external demands, while secondary activities represent those conducted to serve the needs of internal customers. The difficulty lies in the fact that the secondary activities and output are consumed not only by the main activity but also by the secondary activities themselves.

\section{Previous Studies}

A study conducted by Oseifuah (2013) in Buffalo City Municipality, Eastern Cape Province, South Africa yielded research results to support the premise that $A B C$ is an effective way of obtaining useful information and costs that can be compared. It will lead to an increase in financial performance, cost information for decision-making and services in the public sector.

Carmo (2012) conducted a study to evaluate the progress and challenges in the adoption of $A B C$ in the public sector. The study compared the implementation of $A B C$ in the public sectors of several countries, Colombia, Uruguay and Brazil, based on the experience of the US. In this context, this study demonstrated that the use of an $A B C$ cost management system for public sector information in Latin America remains at only a partial or early stage. However, there is consensus on the promotion of a higher degree of transparency and accountability in public expenditure and on spreading the 'cost culture' in public sector administration.

Studies on the use of the $A B C$ method in public sector organisations in Indonesia remain few in number and mostly deal with profit-oriented government organisations, such as hospitals and universities. Based on the importance of government service product cost information and to add to the research literature on $A B C$ in the Indonesian public sector, this study has a research focus on two research questions (RQ):

$R Q_{1}$ : How can we calculate product cost using the $A B C$ method in a governmental organisation, especially in KPPN Jakarta IV?

$R Q_{2}$ : What is the prospect of implementing $A B C$ in a governmental organisation, especially in KPPN Jakarta IV?

$R_{1}$ is answered by analysing documents and calculating product costs using the $A B C$ method, while $R Q_{2}$ is analysed via qualitative analysis using interview data with coding, describing and comparing, and categorising and conceptualising (Hennink, Hutter, \& Bailey, 2011).

\section{Research Method}

This research is qualitative in nature and employs an interpretive strategy case study (Creswell, 2014). The data analysis in this research is carried out 
in two ways, namely calculation document analysis using the $A B C$ method and qualitative analysis using interview data. The core of the data analysis and interpretation, in line with Hennink et al. (2011), was carried out according to the analytic cycle. The analytic cycle consists of four stages: coding; describe and compare; categorise and conceptualise; developing a theory. The four stages of the analytic cycle are not only circular and repeated but also simultaneously conducted at various points in the analysis.

There are two types of data source in this study, namely financial data and interview data. The financial data used are derived from the Jakarta IV KPPN financial documents used to calculate the unit cost of the product using the $A B C$ method. The financial data include the Budget Realization Report (LRA); Activity Operational Directive (POK); Salary list of employees; List of overtime and employee meal cost; and Standard Operating Procedure.

The interview data were obtained from the results of direct interviews with the management/staff of KPPN Jakarta IV. These individuals include the Head of Office, Section Head of Disbursement, Section Head of Satker and Internal Compliance Management, and the staff of KPPN Jakarta IV. The interview data are used for qualitative analysis to determine the conceptual framework of the prospect of implementation of the ABC method at KPPN Jakarta IV.

The data analysis in this research is conducted in two ways: a document analysis with the $A B C$ calculation method and qualitative analysis of interview data.

\section{1) Analysis of documents ( $A B C$ calculation method)}

Regarding the calculation of the unit cost of products, the researcher used three basic studies from Roztocki et al. (2004), Mulyadi (2007), and Popesko (2009). The calculation consists of two stages, as shown in Figure 2: Activitybased process costing and Activity-based object costing.

\section{Activity-Based Process Costing}

The main concept in this step is the allocation of resource consumption to activity. At this stage, costs are divided by their function, i.e. as investment and non-investment costs. Investment costs are costs associated with the formation of fixed assets (capital expenditure), while non-investment costs comprise employee costs and goods cost (operational expenditure). Investment costs are excluded from the calculation because they are not directly related to the product.

Furthermore, operating costs are classified into two categories - the direct costs of product/service and the indirect costs of products/services (Mulyadi, 2007). The direct costs of product/service are those costs that can be directly charged to the product/service. This fee is charged to the activities that produce the products/services, such as production activities payment. It consists of direct labour and direct material costs. The indirect costs of products/services are those costs that cannot be directly charged to 


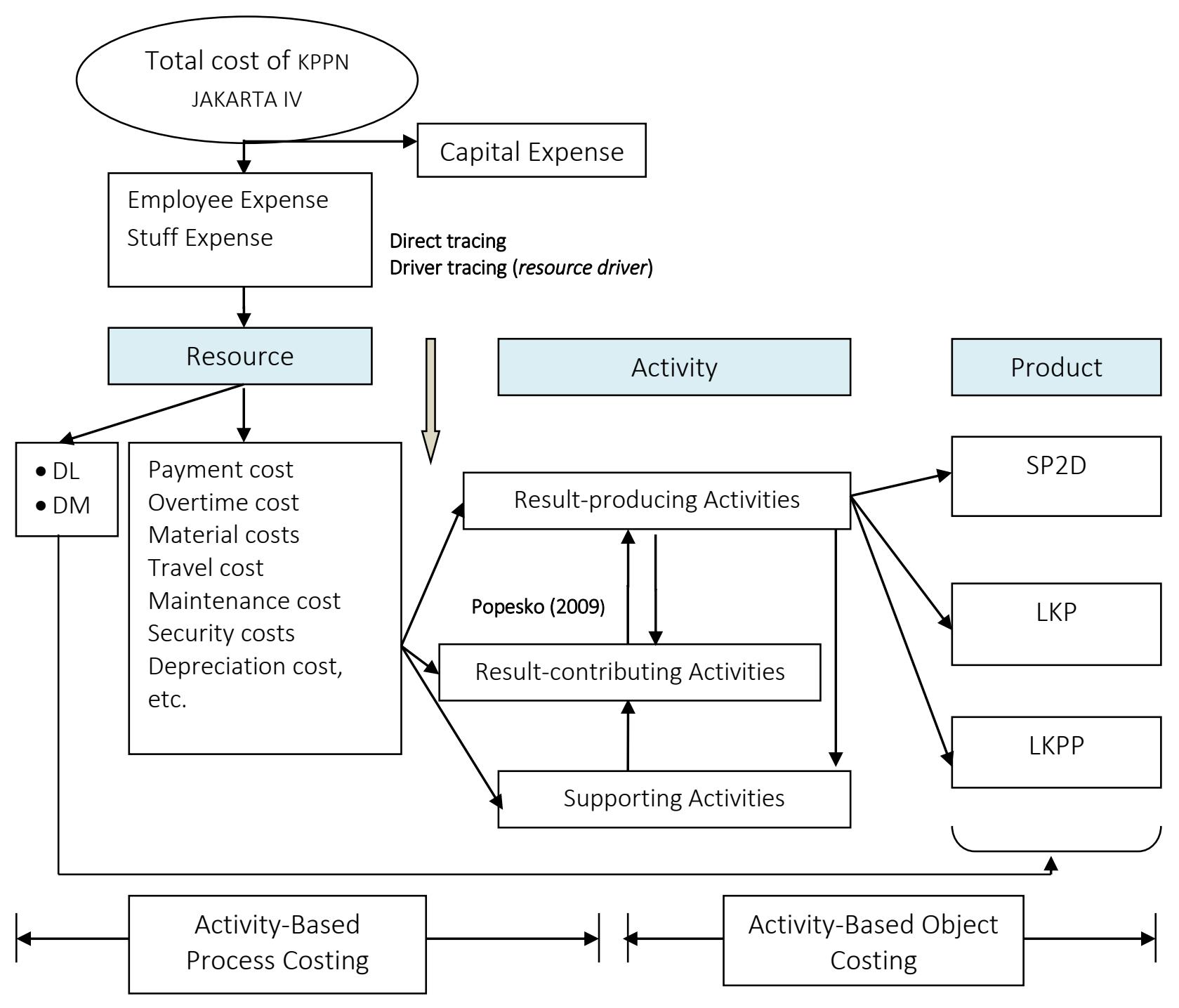

Figure 2 ABC Calculation Document Analysis

Source: Roztocki et al. (2004); Mulyadi (2007); Popesko (2009)

the product/service. They are divided into two - the direct and indirect costs of activity.

A direct cost of activity is a cost that can be charged directly to an activity, which entails the charging of cost to an activity through the direct identification of resource consumption by that activity. The indirect costs of activity are those costs that cannot be directly charged to an activity. These are then charged to activity in two ways - driver tracing and allocation. Driver tracing is charged to the activity through a resource driver, namely the causal relationship between resources consumption and activity.

Allocation is charged to activity through specific allocations. The allocation is conducted using the Activity Expenses-Dependence (EAD) matrix (Roztocki et al., 2004). The EAD method uses a dependency matrix linking activity with cost. The relevant percentage of the dependence matrix is derived from the questionnaires completed by or the interviews conducted with participants. 
At this stage of Activity-Based Process Costing, the allocation of the consumption of resources to the activities is carried out in three ways: direct search, triggers search and allocation. Identifying and determining the most appropriate trigger (i.e. cost driver) is the biggest challenge associated with the ABC method (Goldsby \& Closs, 2000).

\section{Activity-Based Object Costing}

This second phase has three important processes: (1) the formation of a homogeneous activity cost pool, (2) the imposition of cross-activity cost, and (3) the charging of production activity to every product.

\section{2) Qualitative analysis of interview data}

The core of data analysis and interpretation according to Hennink et al. (2011) is carried out according to the analytic cycle. The analytic cycle consists of four stages: coding; describe and compare; categorise and conceptualise, and developing a theory. The four stages of the analytic cycle are not only circular and repeated but are also simultaneously conducted at various points of the analysis.

\section{Result and Discussion}

\section{1) Document Analysis ( $A B C$ calculation method)}

The calculation consists of two stages: activity-based process costing and activity-based object costing.

\section{Activity-Based Process Costing}

a. Identify the types of products of KPPN Jakarta IV.

The first stage in the $A B C$ method is determining the primary products of a specific organisation. Based on the POK, there are three services produced by KPPN Jakarta IV: Fund Disbursement Order (SP2D); Statements of Cash Position (LKP); and the Central Government Financial Report (LKPP).

b. Identify resources and determine the direct cost, indirect costs and the investment cost.

Data on resources were obtained from the amount of budget managed by KPPN Jakarta IV during the period of fiscal year 2015. Because this analysis is based on actual cost, the resource base is taken from the amount of expenditure realized by KPPN Jakarta IV. The total cost was IDR $5,587,775,475$, coupled with a depreciation cost of IDR 280,963,233. Investment costs of IDR $321,831,100$ are excluded from the calculation because they do not relate directly to production (Table 1).

c. Categorise the activity and activity cost.

According to Mulyadi (2007), activity is divided into three categories: supporting activities, result-contributing activities and result-producing activities. Regarding the three activity categories, the identified costs are 
Table 1 Cost

\begin{tabular}{|rlr}
\hline No. & \multicolumn{1}{c}{ Cost } & \multicolumn{1}{c}{ Total (IDR) } \\
\hline 1. & Administration and finance & $866,909,325$ \\
\hline 2. & Meal allowance & $396,571,000$ \\
\hline 3. & Overtime & $403,990,000$ \\
\hline 4. & Office correspondence & $16,759,839$ \\
\hline 5. & Medicine and doctor & $31,309,278$ \\
\hline 6. & Meal for guests/meetings & $114,473,674$ \\
\hline 7. & Employee uniforms & $34,220,000$ \\
\hline 8. & Website management & 766,776 \\
\hline 9. & Security, driver and waiter & $169,960,000$ \\
\hline 10. & Equipment and machine maintenance & $46,043,700$ \\
\hline 11. & Vehicle maintenance & $55,064,893$ \\
\hline 12. & Employee competence improvement & $92,400,000$ \\
\hline 13. & Telephone cost & $17,181,129$ \\
\hline 14. & Cost of depreciation & $280,963,233$ \\
\hline 15. & MSKI service & $421,512,368$ \\
\hline 16. & SP2D & $99,009,645$ \\
\hline 17. & LKPP & $156,266,026$ \\
\hline 18. & LKP & $45,376,000$ \\
\hline 19. & SP2D direct material cost & $1,071,084,849$ \\
\hline 20. & LKP direct material cost & $490,856,501$ \\
\hline 21. & LKPP direct material cost & $574,824,838$ \\
\hline 22. & SP2D direct labour cost & $65,285,350$ \\
\hline 23. & LKP direct labour cost & $29,628,500$ \\
\hline 24. & LKPP direct labour cost & $40,677,000$ \\
\hline 25. & Investment & $321,831,100$ \\
\hline & & \\
\hline
\end{tabular}

entered into the categories of existing activity. The classification of activities and costs into three categories can be seen in Table 2 .

\section{Activity-based object costing}

a. Conduct cross-activity charging

In the first instance, activity costs are charged from supporting activities to product contribution activity and result-producing activity. This step is based on the cost drivers that is the amount of supporting activities consumed by the product contribution activity and result-producing activity. Once the cost driver has been determined, cost driver rates can be measured by dividing the total cost of the activity by the number of cost drivers. The next step, which is based on the amount of cost triggered, entails allocating the expense of the supporting activity to product contribution activity and result-producing activity, as can be seen in Table 3. Moreover, the cost amounts of product contribution activity and result-producing activity following the charging from supporting activity are given in Table 4.

Although each activity cost of product contribution activity and resultproducing activity has been divided by the product, in actual fact, crossactivity in KPPN is interrelated. Popesko (2009) highlighted the existence of mutual cross-activity consumption and also self-consumption. Thus, the 
Table 2 Category of Cost

\begin{tabular}{clrc}
\hline No. & Cost & Total (IDR) & Categorr \\
\hline 1. & Administration and finance & $866,909,325$ & Result-contributing activities \\
2. & MSKI service & $421,512,368$ & Result-contributing activities \\
3. & Meal allowance & $396,571,000$ & Supporting activity \\
4. & Overtime & $403,990,000$ & Supporting activity \\
5. & Office correspondence & $16,759,839$ & Supporting activity \\
6. & Medicine and doctor & $31,309,278$ & Supporting activity \\
7. & Meal for guests/meetings & $114,473,674$ & Supporting activity \\
8. & Employee uniforms & $34,220,000$ & Supporting activity \\
9. & Website management & 766,776 & Supporting activity \\
10. & Security, driver and waiter & $169,960,000$ & Supporting activity \\
11. & Equipment and machine & $46,043,700$ & Supporting activity \\
12. & Vehiclenance maintenance & $55,064,893$ & Supporting activity \\
13. & Employee competence & $92,400,000$ & Supporting activity \\
14. & Telephone cost & $17,181,129$ & Supporting activity \\
15. & Cost of depreciation & $280,963,233$ & Supporting activity \\
16. & SP2D & $99,009,645$ & Result-producing activities \\
17. & LKPP & $156,266,026$ & Result-producing activities \\
18. & LKP & $45,376,000$ & Result-producing activities \\
\hline
\end{tabular}

amount of each cross-activity consumption, which is based on a percentage, should be calculated.

The calculation of cross-activity consumption in KPPN Jakarta IV on a cost analysis basis using the $A B C$ method can be seen in Table 5 .

b. Determining the Total of Product Cost

The final stage in the calculation of the cost of products for KPPN Jakarta IV is to total the cost that has been calculated by the direct costs, including both direct labour costs and direct material costs. This phased calculation of the total cost can be seen in Table 6 .

Furthermore, based on the calculation results in Table 6 , it is possible to determine the cost per product unit at KPPN Jakarta IV. The cost is obtained by dividing the total product cost derived from the $A B C$ results by the number of product units produced. The SP2D amount of 125,574 was obtained from the State Budget Treasury Systems (SPAN) application, while the 252 LKP and 12 LKPP were obtained from POK 2015. The calculation of cost per product unit can be seen in Table 7 .

The cost per product unit can be measured accurately because the cost is traced from all costs that have been budgeted at DIPA KPPN Jakarta IV. In addition, the total product cost is produced from charging or consumption costs based on the logical relationship of cause and effect, which triggers a different cost for each activity. As a result, the costs per product unit of 


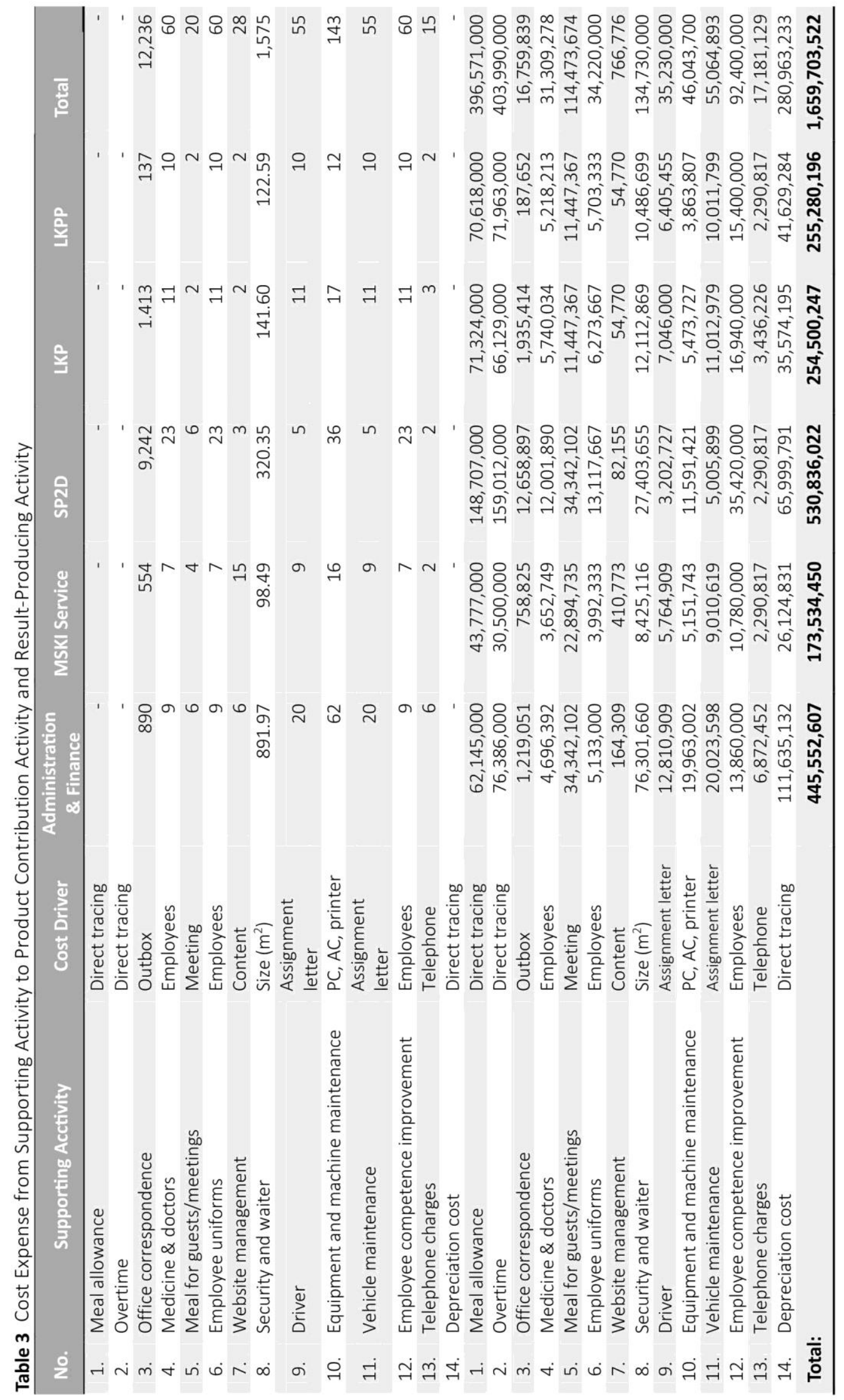


Table 4 Charging of Cost for Supporting Activity

\begin{tabular}{lrrrrr}
\hline Cost & $\begin{array}{c}\text { Administration } \\
\text { \& Finance }\end{array}$ & MSKI Service & \multicolumn{2}{c}{ SP2D } & \multicolumn{2}{c}{ LKP } & \multicolumn{1}{c}{ LKPP } \\
\hline Before Charging & $866,909,325$ & $421,512,368$ & $99,009,645$ & $45,376,000$ & $156,266,026$ \\
Supporting Activities Charging & $445,552,607$ & $173,534,450$ & $530,836,022$ & $254,500,247$ & $255,280,196$ \\
After Charging & $1,312,461,932$ & $595,046,818$ & $629,845,667$ & $299,876,247$ & $411,546,222$ \\
\hline
\end{tabular}

SP2D, LKP and LKPP were IDR 18,068, IDR 2,705,031 and IDR 85,877,867, respectively.

Based on the product cost produced using the $A B C$ method, it is possible to measure product cost in governmental organisations. It is also possible to undertake a comparison between the product costs at KPPN in order to create a benchmark for product cost, performance measurement and costefficiency.

\section{1) Qualitative analysis of interview data}

According to Hennink et al. (2011), qualitative data analysis consists of four stages: coding, describing, categorising and conceptualising and developing the theory.

Drawing up the code relates to the initial procedure of qualitative analysis to identify the code in the form of topics, issues, ideas or opinions that are evident through the interview transcript. Interview transcripts totalling 35 sheets in length were produced based on the recordings from five participants. Any topic related to the $A B C$ products in the interview transcripts were marked (yellow sign). Each topic or emerging issue was identified and defined with the use of a code (coding). This coding process generated a total of 30 codes.

Table 5 Percentage of Cross-Activity Cost Consumption

\begin{tabular}{|c|c|c|c|c|c|c|}
\hline Activities & $\begin{array}{l}\text { Administration } \\
\text { \& Finance }\end{array}$ & MSKI Service & SP2D & LKP & LKPP & Total \\
\hline & $312,461,932$ & $595,046,818$ & $629,845,667$ & $299,876,247$ & $411,546,222$ & $3,248,776,886$ \\
\hline $\begin{array}{l}\text { Administration } \\
\text { \& Finance }\end{array}$ & $78 \%$ & $13 \%$ & $9 \%$ & - & - & $100 \%$ \\
\hline MSKI Service & - & $58.10 \%$ & $33.90 \%$ & $3.20 \%$ & $4.80 \%$ & $100 \%$ \\
\hline SP2D & - & - & $92.00 \%$ & - & $8.00 \%$ & $100 \%$ \\
\hline LKP & - & - & $46.20 \%$ & $47.40 \%$ & $6.40 \%$ & $100 \%$ \\
\hline LKPP & - & - & $23.00 \%$ & - & $77.00 \%$ & $100 \%$ \\
\hline $\begin{array}{l}\text { Administration } \\
\text { \& Finance }\end{array}$ & $1,023,720,307$ & $170,620,051$ & $118,121,574$ & - & - & $1,312,461,932$ \\
\hline MSKI Service & & $345,722,201$ & $201,720,871$ & $19,041,498$ & $28,562,247$ & $595,046,818$ \\
\hline SP2D & & & $579,458,014$ & - & $50,387,653$ & $629,845,667$ \\
\hline LKP & & & $138,542,826$ & $142,141,341$ & $19,192,080$ & $299,876,247$ \\
\hline LKPP & & & $94,655,631$ & - & $316,890,591$ & $411,546,222$ \\
\hline Total & $1,023,720,307$ & $516,342,252$ & $1,132,498,916$ & $161,182,839$ & $415,032,571$ & $3,248,776,886$ \\
\hline
\end{tabular}


Table 6 Product Cost Totals

\begin{tabular}{lrrr}
\hline Calculation & \multicolumn{1}{c}{ Product } \\
\hline Cost & \multicolumn{1}{c}{ LKP } & \multicolumn{1}{c}{ LKPP } \\
\hline Direct Labour Cost & $1,132,498,916$ & $161,182,839$ & $415,032,571$ \\
Direct Material Cost & $1,071,084,849$ & $490,856,501$ & $574,824,838$ \\
Total Cost & $65,285,350$ & $29,628,500$ & $40,677,000$ \\
\hline
\end{tabular}

In the describing phase, the 30 codes were described in as much detail as possible to enable the researcher to become more familiar with and access the depth of each code and code network in an interview transcript. The intensity of each code was also calculated. The intensity of the code shows the strength of the influence or the context of each code.

For the categorising and conceptualising stage, once the 30 codes had been described and compared, they were then grouped according to their similar characteristics. A total of seven categories were produced, comprising 22 codes, while the other eight codes were removed due to the fact that they had minimal impact and would have raised new questions. Furthermore, by taking into account the relationship between these categories and by viewing the data as a whole, the researcher compiled a conceptual understanding of the existing categories. The results from the qualitative analysis related to the understanding of the prospect of utilising the $A B C$ concept are given in Figure 3.

The $A B C$ quantitative analysis and qualitative analysis of the interviews resulted in a range of findings which are discussed as follows:

\section{1) The calculation of the product cost}

Up to now, the Indonesian government has not conducted product cost analysis from any non-profit governmental organisations, meaning the results of this study may open up the possibility of this $A B C$ method being used in all governmental organisations/agencies in Indonesia.

This study not only uses the original $A B C$ concept based on Kaplan and Cooper (1998) but also incorporates a range of other ABC-related concepts, namely those by Kaplan and Cooper (1998), Roztocki et al. (2004), Mulyadi (2007), and Popesko (2009). The expected result is far more accurate and relevant research into the use of the $A B C$ method.

The use of $A B C$ in this study has shown to be suitable for determining the cost per product unit at one non-profit governmental organisation in

Table 7 Cost per Product Unit

\begin{tabular}{lccc}
\hline Calculation & \multicolumn{3}{c}{ Product } \\
& SP2D & LKP & LKPP \\
\hline Total Cost & $2,268,869,115$ & $681,667,840$ & $1,030,534,409$ \\
Total Units & 125,574 & 252 & 12 \\
Cost per unit (IDR) & 18,068 & $2,705,031$ & $85,877,867$ \\
\hline
\end{tabular}


Indonesia, that of KPPN Jakarta IV. As a result, the costs per product unit for SP2D, LKP and LKPP were IDR 18,068, IDR 2,705,301 and IDR 85,877,867, respectively.

This success may raise awareness of the potential for implementing $A B C$ in all governmental organisations in Indonesia. As a result, the cost of service product can be compared among government agencies that have the same level and type. Moreover, this success also reinforces the premise by Chea (2011) and Michel (2004) that the application of ABC may not be restricted only to the private sector, but that it can also be implemented within a governmental organisation.

\section{2) Lack of tools}

Until now, KPPN Jakarta IV has had no form of analytical tool with which to calculate product cost, which is a condition that may also be replicated in all governmental organisations in Indonesia. In the absence of such analysis tools, the management at government agencies measure organizational

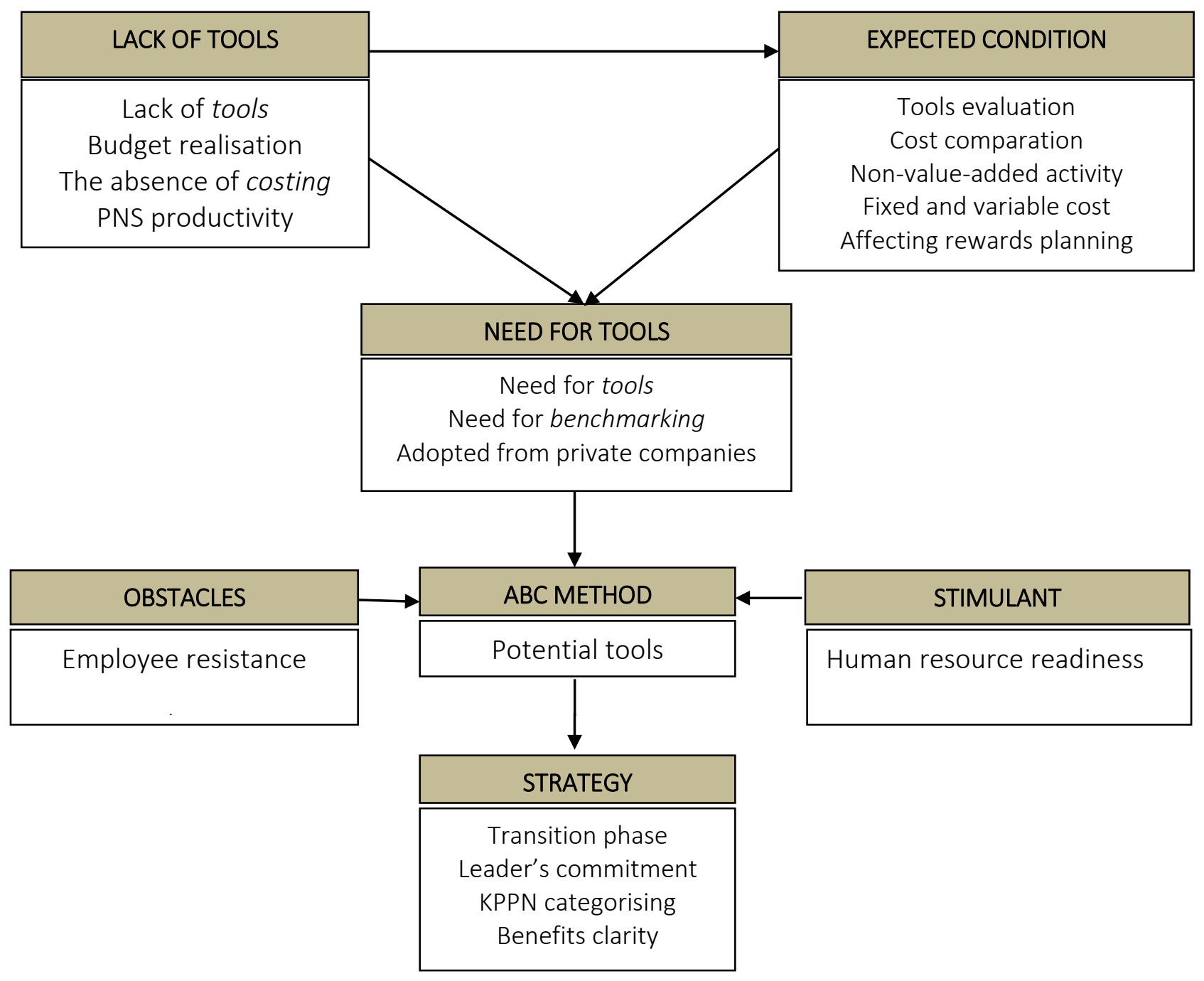

Figure 3 Conceptual Framework of ABC Prospect 
performance based only on targets for budget realisation. This corresponds to the answers given by the participants in this study:

"No, we are in the public sector, it is difficult to measure the size of the cost incurred. If I think finding the level of efficiency is difficult, below cannot be measured. In a sense it can be measured, but to date, what is efficient or not we do not know because it has never been measured." (Section Head of Disbursement of KPPN Jakarta IV)

"No, cost analysis does not exist. For example, in the private [sector], if there is a product there must be costing, to achieve the number of specific products, and what it costs. Whether efficient or not, in the private it can be measured. Well, we with this product, no matter what resources are used, we cannot, there is no size, so just be." (Section Head of Disbursement of KPPN Jakarta IV)

Additionally, the absence of any benchmarks for product cost and costefficiency in government services can be attributed as a cause of less optimal performance.

\section{3) Internal awareness}

This study has found, however, that the top management of KPPN Jakarta IV do indeed realise and need a method of product cost analysis so that they can measure cost effectiveness in each part/activity issued to produce the product. This study also uncovered the importance of raising the awareness that cost analysis is important for KPPN Jakarta IV.

"I am sure that human resources in KPPN, especially KPPN Jakarta IV, will be ready to respond to it all, since we have always been accustomed and ready to adjust to the situation and the changes in a better direction, because in the context of service we must always change towards better. If there is information, new things related to improving the quality of service, we from the executor, section, head office, even the top leaders will also prepare for it, I'm sure this will be well received." (Head of KPPN Jakarta IV)

However, change and improvement must come from within the organisation itself, which means that all employees should accept $A B C$ and be responsible for its implementation (Chea, 2011).

\section{4) Employee resistance}

All of the participants in this study argued that there is great potential for the employees at KPPN Jakarta IV to reject the implementation of ABC. This rejection arises from employees in public sector organisations regarding the implementation plan of $A B C$.

"That's normal. I'm sure, every new one is a challenge because not everyone can immediately understand something new. There are people keep thinking conventional, this is good why should be like this. But I think if there is a better, why should it not be done, why we do not follow it? We must follow the challenges of the times." (Section Head of Satker and Internal Compliance Management of KPPN Jakarta IV) 
"Every employee is not the same, some are quick to absorb, some are normal, some are slow, some accept sincerely, happy to be done, some are moderate, and some refuse first." (Head of KPPN Jakarta IV)

Such employee resistance to change is in line with research by Lutilsky and Dragija (2012) and Morgan (1993). Although it is likely that the number of such employees would be small, it nonetheless remains a concern for decision makers. This rejection was driven by the different responses to the implementation plan of $\mathrm{ABC}$, whereby some people accepted the plan, some refused in advance and some were moderate. In addition, Jones (2014) discussed the weaknesses/obstacles in the implementation of ABC. These include resistance based on a rejection from employees since it involves all departments and may eliminate some activities.

\section{5) Leadership commitment}

The participants in this study from KPPN Jakarta IV also argued that the commitment of leaders in terms of management strategy is an important factor for the success of $A B C$ implementation. They have to serve as the front line and as the driving force in maintaining the successful implementation of the new methods associated with $A B C$.

"If being a leader, inevitably, should be the person at the forefront, accept this and carry out, and handed down to the staff below. If the leader refused to be damaged, it would not work. This means that the actual leadership of the task of management so that what is assigned by the head office can be run well." (Head of KPPN Jakarta IV)

\section{6) Transition phase and clarity of benefits}

The needs of the transition phase, socialisation and the clarity of the impact of $A B C$ usage are also the positive parts of $A B C$ implementation in KPPN Jakarta IV. These findings are in line with Morgan (1993), Lawson (2005) and Chea (2011) who stated that it is difficult to accept the $A B C$ method in the absence of any significant benefits of the early implementation of $A B C$.

"Because in the change, there must be a transition period. With the transition period, we are gradually able to adjust." (Section Head of Disbursement of KPPN Jakarta IV)

"But over time, socialisation and transition time, it is usually we follow." (Section Head of Satker and Internal Compliance Management of KPPN Jakarta IV)

"Now, what effect does this ABC method have on them?" (Staff of Disbursement Section of KPPN Jakarta IV)

The same applies to the methods of Just-in-Time (JIT), Balanced Scorecard (BSC) and Total Quality Management (TQM); as such, ABC is not a magic formula that will necessarily be successful immediately (Morgan, 1993). Every new method that is introduced is part of the improvement process in an organisation's performance. 


\section{7) $A B C$ as a potential method}

The results of this research demonstrate that the management of KPPN Jakarta IV have appraised $A B C$ as a potential method. This result concurs with the approval of $A B C$ as an alternative method that can be recommended for the public sector as also claimed by, for instance, Michel (2004), Cai et al. (2013), and Cokins (2015).

"So that later can be measured. For example, the cost standard for one KPPN is, for example, five rupiah, apparently implemented by KPPN Jakarta IV amounting to six rupiahs or three rupiahs. If three rupiah means KPPN Jakarta IV uses very low cost, it is very effective." (Head of KPPN Jakarta IV)

"Actually this has good potential, to measure us as a service office, now we do not have a definite size. So it should not only be stuck with the target realisation of the budget. That is, we should see performance." (Head of KPPN Jakarta IV)

The author hopes that the $A B C$ method can be adopted and implemented in Indonesia, such as has been the case with the Balanced Scorecard (BSC) method, which has itself been successfully adopted and implemented in Indonesia. Several ministries in Indonesia, including the Ministry of Finance, have used the BSC as a tool for employee performance measurement and utilised it as the basis for the awarding of employee performance allowances. Employee performance allowances at the Ministry of Finance are paid based on each employee's achievement of Key Performance Indicators (IKU).

However, there is no such thing as the best cost analysis method, only the most suitable cost analysis method for use by an organisation's management (Rasiah, 2011). An organisation's management also has to be able to determine the level at which the $A B C$ method is relevant and beneficial for the organisation's performance (Vokurka \& Lummus, 2001). This suggests the need for further research to be conducted in the future regarding the prospective use of $A B C$ in the public sector in Indonesia.

\section{Conclusion}

Based on the results of this study, it is concluded that the cost of each unit of product in one non-profit government agency (KPPN Jakarta IV) can be calculated using the $A B C$ method. The concept of $A B C$ as introduced by Kaplan and Cooper (1996), combined with other ABC method concepts from Roztocki et al. (2004), Mulyadi (2007), and Popesko (2009), are used in this study to successfully determine the cost of 3 (three) products produced by KPPN Jakarta IV, namely LKP, SP2D and LKPP.

The success provides each government agency with the ability to calculate the unit costs of its products. Furthermore, comparisons can be undertaken between similar types and categories of products produced by government agencies. Cost analysis is an important point because it is associated with product cost benchmarking for each governmental instance. In addition, cost 
analysis is related to employee productivity, efficiency, performance evaluation and also as the basis for budget planning.

This research has also found a positive appraisal of the prospect of implementing the ABC method at KPPN Jakarta IV by the management of the government institution. The management at KPPN Jakarta IV have an internal awareness that government agencies in Indonesia do not currently have but do need a product cost analysis tool/tools for the purpose of providing information for use in decision-making. In addition, there are a number of determining factors relating to the context of $A B C$ implementation in government agencies in Indonesia, including the readiness of Human Resources, leaders' commitment, clarity of the impact of $A B C$ and the transition phase or socialisation.

The public sector needs to begin adopting the methods used by private companies, which means that the $A B C$ method as a cost analysis tool can be an alternative for the government to be studied, developed and implemented in a governmental context. Since there has not been any instance of cost analysis implementation in a governmental setting in Indonesia, the implementation of such a method is required. However, it is important to note the complicated nature of a system for calculating costs and that the determination of costs in relation to the product cost is still an estimation (Latshaw \& Cortese-Danile, 2002). Thus, more research on ABC in the public sector in Indonesia is needed in the future.

\section{Acknowledgement}

The author would like to thank the Public Sector Governance (PSG) Faculty of Economics and Business, Universitas Gadjah Mada for the financial support for this research. The authors are also highly appreciative of the reviewers for their criticism, suggestions and feedback on this research in order to make this paper more qualified.

\section{References}

Cai, X., Moore, E., \& McNamara, M. (2013). Design an activity-based costing model for a non-admitted prisoner healthcare setting. Australian Health Review, 37(4), 418-422. https://doi.org/10.1071/ah12023

Carmo, L. P. F. (2012). Advances and challenges for adoption of Activity Based Costing (ABC) by public sector: A comparative study of Brazil, Colombia, Uruguay and United States. International Business Research, 5(2), 150. https://doi.org/10.5539/ibr.v5n2p150

Chea, A. C. (2011). Activity-based costing system in the service sector: A strategic approach for enhancing managerial decision making and competitiveness. International Journal of Business and Management, 6(11), 310. https://doi.org/10.5539/ijbm.v6n11p3

Cokins, C. (2015). A need for better cost information in the public sector. Retrieved May 15, 2018 from https:/ / mw ifac.org/global-knowledgegateway/business-reporting/discussion/ need-better-cost-information-public-sector. 
Cokins, C., Helbling, J., \& Stratton, A. (1996). Sistem activity-based costing pedoman dasar bagi manajer. Jakarta: PT Pustaka Binaman Pressindo.

Creswell, J. W. (2014). Research design: Qualitative, quantitative, and mixed methods approaches. Los Angeles, London, New Delhi, Singapore: SAGE Publications, Inc.

Datar, S., \& Gupta, M. (1994). Aggregation, specification and measurement errors in product costing. The Accounting Review, 69(4), 567-591.

Goldsby, T. J., \& Closs, D. J. (2000). Using activity-based costing to reengineer the reverse logistics channel. International Journal of Physical Distribution \& Logistics Management, 30(6), 500-514. https://doi.org/10.1108/09600030010372621

Harrison, D. S. (1998). Activity-based costing and warm fuzzies-costing, presentation and framing influences on decision-making $\sim$ a business optimization simulation $\sim$. Dissertation proposal at the faculty of Virginia Polytechnic Institute and State University, The degree of Doctor of Philosophy in Business with a major in Accounting. Retrieved April 30, 2018 from http://search.proquest.com.ezproxy.ugm.ac.id/docview/304459221/full textPDF/1432D769FEF04C61PQ/1? accountid=13771.

Hennink, M., Hutter, I., \& Bailey, A. (2011). Qualitative research methods. London: SAGE Publications, Inc.

Horngren, C. T., Datar, S. M., Foster, G., Rajan, M., \& Ittner, C. (2009). Cost accounting: A managerial emphasis. 13th ed. New Jersey: Pearson Education.

Jones, D. J. (2014). Ripken Products: A case for learning activity-based costing. Journal of Business Case Studies, 10(2). https://doi.org/10.19030/ibcs.v10i2.8502

Kaplan, R. S., \& Anderson, S. R. (2004). Time-driven activity-based costing. Harvard Business Review, 82(11), 131-138. https://doi.org/10.2139/ssrn.485443

Kaplan, R. S., \& Cooper, R. (1998). Cost \& effect: Using integrated cost systems to drive profitability and performance. Boston, MA: Harvard Business School Press.

Kont, K-R. (2011). New cost accounting models in measuring of library employees' performance. Library Management, 33(1/2), 50-65. https://doi.org/10.1108/01435121211203310

Latshaw, C. A., \& Cortese-Danile, T. M. (2002). Activity-based costing: Usage and pitfalls. Review of Business, 23(1), 30-32.

Lawson, R. A. (2005). The use of activity-based costing in the healthcare industry: 1994 vs. 2004. Research in Healthcare Financial Management, 10(1), 77-94.

Lutilsky, I. D., \& Dragija, M. (2012). Activity based costing as a means to full costing-possibilities and constraints for European universities. Management, 17(1), 33-57.

Mardiasmo (2009). Akuntansi Sektor Publik. Cetakan ke-4. Yogyakarta: ANDI.

Michel, R. G. (2004). Cost analysis and activity-based costing for government. GFOA Budgeting Series Vol. 6.

Morgan, M. J. (1993). Testing activity-based costing relevance: Pharmaceutical Products Limited-case study. Management Decision, 31 (3), 8. https://doi.org/10.1108/00251749310036289

Mowen, M. M., Hansen, D. R., \& Heitger, L. (2012). Managerial accounting: The cornerstone of business decisions, Fourth ed. International edition. Boston, MA: Cengage Learning, Inc.

Mulyadi (2007). Activity-based cost system. Sistem informasi Biaya untuk Pemberdayaan Karyawan, Pengurangan Biaya, dan Penentuan Secara Akurat Kos Produk dan Jasa (Edisi ke-6 Cetakan ke-2.). Yogyakarta: UPP STIM YKPN. 
Oseifuah, E. K. (2013). Activity based costing approach to financial management in the public sector: The South Africa experience. European Scientific Journal, 9(1).

Popesko, B. (2009). How to manage the costs of service departments using Activity-Based Costing. International Review of Business Research Papers, 5(4), 91-101.

Rasiah, D. (2011). Why Activity Based Costing (ABC) is still tagging behind the traditional costing in Malaysia? Journal of Applied Finance and Banking, 1(1), 83-106.

Roztocki, N., Porter, J. D., Thomas, R. M., \& LaScola Needy, K. (2004). A procedure for smooth implementation of activity-based costing in small companies. Engineering Management Journal, 16(4), 19-27. https://doi.org/10.1080/10429247.2004.11415262

The Global Competitiveness Report 2015-2016. World Economic Forum. bttp:// www3.weforum.org/docs/gcr/2015-2016/IDN.pdf

Verbeeten, F. H. M. (2011). Public sector cost management practices in the Netherlands. International Journal of Public Sector Management, 24(6), 492506. https://doi.org/10.1108/09513551111163620

Vokurka, R. J., \& Lummus, R. R. (2001). At what overhead level does activitybased costing pay off? Production and Inventory Management Journal, 42(1), 40.

Weygandt, J. J., Kieso, D. E., \& Kell, W. G. (1996). Accounting principles. $4^{\text {th }}$ ed. New York: John Willey \& Sons, Inc.

Worldwide Governance Indicators 1996-2016. World Bank. bttp://info.worldbank.org/governance/wgi/\#reports

\section{Regulation:}

Republik Indonesia. (2010). Peraturan Pemerintah Nomor 71 Tahun 2010 tentang Standar Akuntansi Pemerintahan.

Kementerian Keuangan. (2015). Peraturan Menteri Keuangan Nomor 65/PMK.02/2015 tentang Standar Biaya Masukan Tahun Anggaran 2016.

Kementerian Keuangan. (2015). Peraturan Menteri Keuangan Nomor 115/PMK.02/2015 tentang Standar Biaya Keluaran Tahun Anggaran 2016. 